\title{
Dimensional accuracy of vinyl polyether and polyvinyl siloxane impression materials in direct implant impression technique for multiple dental implants
}

\section{Purpose}

The present study compared the dimensional accuracy of vinyl polyether silicone (VPES) and polyvinyl siloxane (PVS) impression materials used for non-splinted (NS) and splinted (S) direct open-tray impression techniques for multiple implants inserted in simulated edentulous mandibles.

\section{Materials and Methods}

A mandibular stainless steel model with eight internal connections for implant analogs was fabricated to simulate a clinical scenario. The acrylic resin splinted and non-splinted direct impressions were obtained for both VPES and PVS materials. Seventy-two cast samples were divided into four groups based on the impression techniques and materials used. The dimensional accuracies of the casts were measured in three different axes using a computerized coordinate measuring machine (CMM), and were statistically compared.

\section{Results}

The differences in the distortion values between the VPES and PVS impression materials were not statistically significant. Similarly, the differences between the splinted and non-splinted groups among the VPES and PVS materials were not statistically significant.

\section{Conclusion}

The casts fabricated from VPS or PVS impression materials provide similar dimensional accuracy regardless of the implant splinting method.

Keywords: Dental implants, Direct impressions, Polyvinyl siloxane, Vinyl polyether silicone, Dimensional accuracy

\section{Introduction}

Implant-supported prostheses have become an essential treatment modality $(1,2)$. The passive fit of the implant-supported superstructure is an important factor that determines the treatment success (3). The mismatch between osseous implants and their superstructures induces stresses in prostheses, implants, and peri-implant structures $(4,5)$. Fit precision depends on many factors, among which the impression and an accurate master cast are vital components (6). The factors that influence the cast accuracy are the characteristics of the impression material, technique, type of tray, die material, implant angulation, and fit tolerance between the implant components and transfer copings (7-12). In the case of multiple implants, the quality of the final impression and transfer of the exact positions of the implants to the model are of utmost importance (13).

Various impression techniques have been considered for obtaining accurate master casts $(14,15)$. Open and closed tray techniques are the most

\author{
Rohini Rajendran ${ }^{1}$ (D), \\ N. Gopi Chander ${ }^{1}$, \\ Kuttae Vishwanathan \\ Anitha ${ }^{1}$ iD, \\ Balasubramanian \\ Muthukumar' ${ }^{1}$ iD
}

ORCID IDs of the authors: R.R. 0000-0003-2278-6553; N.G.C. 0000-0002-2040-4550; K.V.A. 0000-0003-0180-9568; B.M. 0000-0002-4022-6456

'Department of Prosthodontics, SRM Dental College, Chennai, TamilNadu, India

Corresponding Author: N. Gopi Chander E-mail:_drgopichander@gmail.com Received: 5 January 2020 Revised: 22 April 2020 Accepted: 16 October 2020 
commonly used protocols. Previous studies have demonstrated that the open-tray technique is more accurate than the closed-tray method $(16,17)$. Herbst et al. (18) observed no difference between splinted and non-splinted impression copings. Assuncao et al. (19) inferred that splinting impression copings with acrylic resin provided favourable results in angled implants. Papaspyridakos et al. (20) reported that the splinted technique produced master casts that were more accurate than the ones produced using the non-splinted method, for one-piece implant-supported fixed dental prostheses in edentulous jaws. Inconsistent findings have been reported in various studies regarding splinted or non-splinted impression copings $(21,22)$.

Different materials have been considered for making implant impressions. Polyether (PE) and polyvinyl siloxane (PVS) have been selected as materials of choice $(15,16,23)$. Studies have justified the use of PE as an impression material for multiunit implant-retained restorations in completely edentulous situations, because it has the property of low strain during compression, with the most advantageous Shore A hardness value $(24,25)$. Further, the PVS impression material aids in easy removal of the set impression owing to its suitable modulus of elasticity; thus, it has been suggested as a preferred material for the direct implant impression technique (13). The advantages and limitations of these materials have led to the development of new-generation vinyl PE silicone (VPES) impression materials that combine the benefits of the PE and PVS materials. These novel materials are hydrophilic and combine the most desired properties of both materials $(11,26)$. Limited research and evidence are available in the literature to recognize the dimensional accuracy of these novel materials over PVS in situations of multiple-implant impression making.

The present study aimed to evaluate and compare the dimensional accuracy of the VPES and PVS impression materials in direct tray splinted and non-splinted approaches to multiple-implant impressions. The null hypothesis tested is that no difference would be detected between the dimensional accuracies of the two impression materials and the splinted and non-splinted techniques.

\section{Materials and methods}

\section{Model design}

The study was approved by the Institutional Review Board (SRMDC/IRB/2015/MDS/NO:202). A standard mandibular stainless-steel reference model was milled to simulate the clinical scenario of the direct implant impression technique (26). A completely edentulous, die stone cast of the mandible was selected and three-dimensional (3D) scanning was performed using CAD CAM. A reference model was fabricated using CAD CAM with the grade 404 stainless steel material (Siva Shakthi Engineering Works, India). Eight sites with dimensions of $3.5 \mathrm{~mm} \times 10 \mathrm{~mm}$ (Adin Dental Implant Systems Ltd, India) were selected at the lateral incisor, canine, second premolar, and molar regions on either side of the arch. A three-axis vertical milling machine (Denford VMC 1300, Denford Ltd., UK) was used to ensure parallelism among the implants. They were sequentially described by letters $A$ to $H$ from the left-most posterior to the right distal implant site.
The tray thickness, spacer, positioning, and impression were performed as described previously (27). 2-mm-wide and 1-mm-deep grooves were made in three different places for effective positioning, stabilization of the tray during impression procedures and to obtain uniform thickness of impression materials. The two posterior grooves were placed between implants $A$ and $H$, and the anterior groove was placed between implants $\mathrm{D}$ and $\mathrm{E}$.

\section{Impression taking}

Two impression materials, VPES (Figure 2) (EXA'lence 370 regular set; GC, USA) (Product no: 137805, Lot no: 1510051, 1602081) and PVS (GC Flexceed, GC Dental, USA) (Lot no:1610191), were evaluated for their dimensional accuracy using both the splinted and non-splinted techniques. Eight square-shaped internal connection hexagonal transfer copings were used (Adin Dental Implant Systems Ltd, India) (Figure 1). Each transfer coping was internally secured into the analogue and tightened with a torque wrench calibrated to $10 \mathrm{Ncm}$. The copings were connected by dental floss (Oral B Company, Chennai, India) and wrapped around to act as a scaffold. A pattern resin with thickness of 2-3 mm (GC pattern resin, GC Ltd, India) (Lot no: 1608092) was applied around the impression copings and to the scaffoldings of the dental floss before making the impression, using an incremental application technique with a brush. The splint was cut using 0.17-mm-thick diamond discs (Acurata Manhardt Dental, Chennai, India). The bars were approximately 2-3 $\mathrm{mm}$ in diameter; they were sectioned into a length of approximately $5 \mathrm{~mm}$ and joined using the bead-brushing method after $24 \mathrm{~h}$ with the auto-polymerizing acrylic resin (27-30). Impressions were made immediately after the material was set. Seventy-two samples were analyzed, with 18 samples in each group, listed as follows. Group VPES (S): Direct splinted technique with VPES. Group VPES (NS): Direct non-splinted technique with VPES. Group PVS (S): Direct splinted technique with PVS. Group PVS (NS): Direct non-splinted technique with PVS.

A mandibular edentulous, perforated metal stock tray was used to make impressions. Eight perforations were created in the tray with a round bur (width, $2 \mathrm{~mm}$ ) at the site of the implants, to provide access for the guide pins of the impression copings. The stock trays were coated with a tray adhesive (Universal VPS adhesive, GC India) and allowed to dry for 15 min before making impressions. Both the VPES and PVS impressions were made using a single-step double-mix putty wash impression technique, following the manufacturer's instructions. Impression of the reference stainless steel model was made, and the tray was fully seated on the three location marks of the model and maintained in position throughout the setting time. The stock tray was seated over the guide stops, and a circular piece of steel weighing $1 \mathrm{~kg}$ was placed on the impression tray to standardize the seating load. After the material was set, the tray was removed. One operator made all impressions to reduce inter-operator variability. Retrieved impressions were examined and repeated if any inaccuracies were found such as air voids or material residues between the analogue-impression coping interfaces, and if any separation from the tray was detected. Implant analogs were screwed to the impression copings (Figure 2), and type- 
4 gypsum casts (Ultra Rock die stone, Shruti products, Upleta, India) (Batch no: 170603) were made (Figure 3) $(29,30)$.

\section{Dimensional stability measurements}

The dimensional stability of the impression materials was evaluated for the linear and rotational distortions observed in the casts. A computerized coordinate measuring machine (CMM OL-3020, Opus Precision Instruments, India) with a mechanical probe (diameter, $0.5 \mathrm{~mm}$; resolution, 0.0001 $\mathrm{mm}$ ) was used for measuring the relative linear distortion in the $X, Y$, and $Z$ coordinates of the centers of the implant platforms. The 3D or rotational distortion ( $r$ ) was calculated from the linear displacements using the following formula: $r=\sqrt{x 2+y 2+z 2}$

Linear distortion was evaluated from the left-most posterior implant (implant $A$ ). The centroid of the implant $A$ head was used as a reference from which measurements were made. Linear distortions were defined as absolute differences between the reference model values and the definitive cast in the $\mathrm{X}, \mathrm{Y}$, and $\mathrm{Z}$ directions, and are denoted as $\Delta \mathrm{X}, \Delta \mathrm{Y}$, and $\Delta \mathrm{Z}$.

The reference planes were defined to measure the sample coordinates $(\Delta \mathrm{X}, \Delta \mathrm{Y}$, and $\Delta \mathrm{Z})$.

The center of the implant positioned on the model was scanned using a machine. The $Z$ plane was outlined on the anterior - posterior surface of the implant. The X-plane was expressed as a line transiting through two implant centers perpendicular to the $Z$ plane. Perpendicular to these $X$ and $Z$ planes was the $Y$ plane. The impression analogues were fastened on the implants, and the implants were circularly scanned around the center to establish the $X, Y$, and $Z$ axes. The distances in the three axes were measured as $A B, A C$, $A D, A E, A F, A G$, and $A H$ (between the implants) (Figure 4). A single operator that was blinded to the experimental setup recorded all measurements three times to avoid intra-operator-related errors, and the mean of the values was recorded. The differences in the values for all axes were tabulated and statistically analyzed.

\section{Statistical analysis}

The data was analyzed with SPPS 17.0 (SPSS Inc. Released 2008. SPSS Statistics for Windows, Version 17.0. Chicago, IL, USA) software. Based on the distribution characteristics of the data, the one-way analysis of variance (ANOVA) test was used for multiple comparisons among study groups.

\section{Results}

The mean differences, standard deviation, and statistical data of the various axes and groups are summarized in Table 1. The results suggest no statistically significant relationship pertaining to the axes, materials, and techniques. The 3D displacement (Table 1) suggests no statistically significant relationship between the techniques and materials. The ANOVA test results comparing the splinted and non-splinted groups of the VPES and PVS are listed in Table 2 and Table 3. The results suggest no statistically significant differences $(f(1.27)=$ 3.490, $\mathrm{p}=0.33$ ).

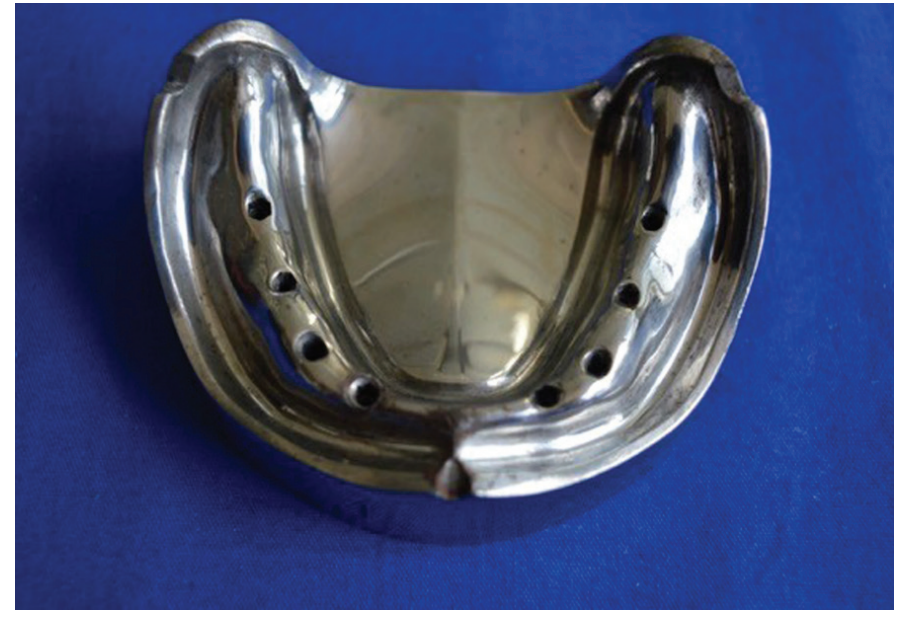

Figure 1. Impression coping attached to the reference model.

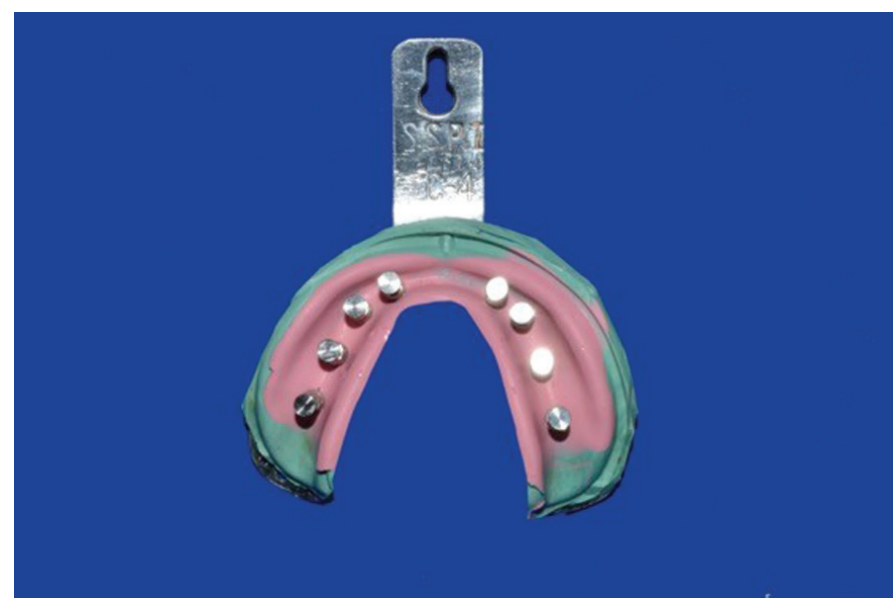

Figure 2. Direct Impression with attached lab analogues.

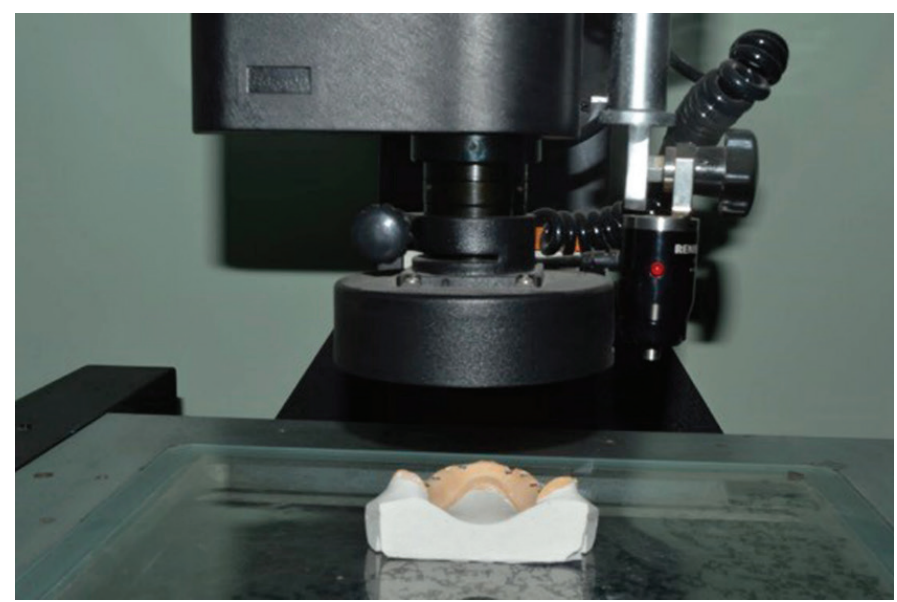

Figure 3. Cast obtained from impression.

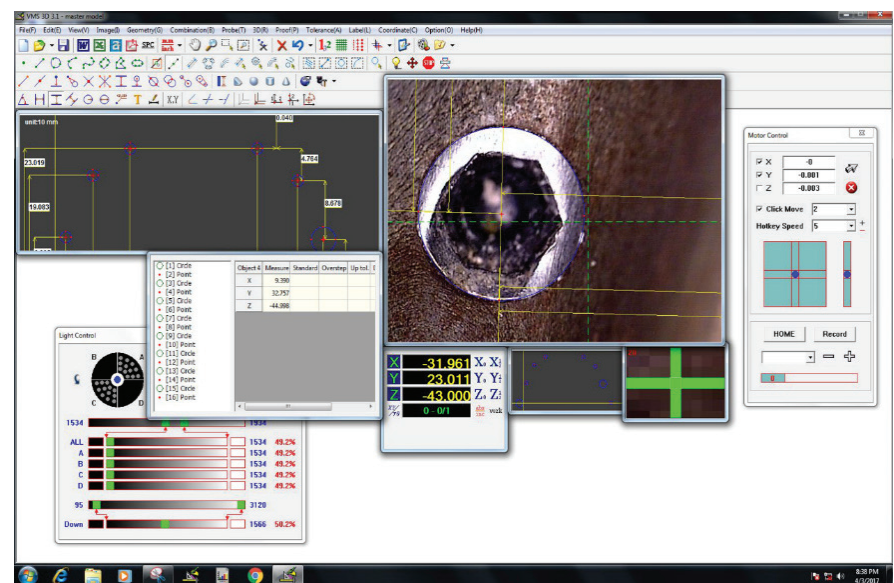

Figure 4. Recorded measurements through the software of CMM. 
Table 1. Mean, standard deviation, $p$ and $F$ values of the splinted and non-splinted impression materials in $\mathrm{mm}$.

\begin{tabular}{|c|c|c|c|c|c|c|c|}
\hline Axis & & $\begin{array}{c}\text { VPES } \\
\text { (S) }\end{array}$ & $\begin{array}{l}\text { VPES } \\
\text { (NS) }\end{array}$ & $\begin{array}{c}\text { PVS } \\
\text { (S) }\end{array}$ & $\begin{array}{l}\text { PVS } \\
\text { (NS) }\end{array}$ & $\begin{array}{c}P \\
\text { value }\end{array}$ & $\begin{array}{c}F \\
\text { value }\end{array}$ \\
\hline \multirow{2}{*}{$\mathrm{X}$ axis } & Mean & 0.11 & 0.18 & 0.15 & 0.16 & \multirow{2}{*}{0.29} & \multirow{2}{*}{1.32} \\
\hline & SD & 0.08 & 0.07 & 0.05 & 0.07 & & \\
\hline \multirow{2}{*}{ Y axis } & Mean & 0.10 & 0.13 & 0.10 & 0.11 & \multirow{2}{*}{0.10} & \multirow{2}{*}{2.30} \\
\hline & SD & 0.02 & 0.08 & 0.07 & 0.07 & & \\
\hline \multirow{2}{*}{$Z$ axis } & Mean & 0.08 & 0.11 & 0.09 & 0.10 & \multirow{2}{*}{0.18} & \multirow{2}{*}{1.76} \\
\hline & SD & 0.04 & 0.05 & 0.04 & 0.05 & & \\
\hline \multirow{2}{*}{$3 \mathrm{D}$} & Mean & 0.16 & 0.27 & 0.22 & 0.30 & \multirow{2}{*}{0.09} & \multirow{2}{*}{2.45} \\
\hline & SD & 0.08 & 0.08 & 0.08 & 0.17 & & \\
\hline
\end{tabular}

Table 2. ANOVA ( Single factor) : Summary statistics between groups.

\begin{tabular}{lcccc}
\multicolumn{1}{c}{ Groups } & Count & Sum & Average & Variance \\
\hline VPES (S) & 4 & 0.37542857 & 0.09385714 & 0.0015738 \\
\hline VPES (NS) & 4 & 0.66457143 & 0.16614286 & 0.00781488 \\
\hline PVS (S) & 4 & 0.53985714 & 0.13496429 & 0.00514211 \\
\hline PVS (NS) & 4 & 0.708 & 0.177 & 0.00300307 \\
\hline
\end{tabular}

Table 3. ANOVA analysis.

\begin{tabular}{lllllll}
$\begin{array}{l}\text { Source of } \\
\text { Variation }\end{array}$ & SS & df & MS & F & $\begin{array}{l}\text { P } \\
\text { value }\end{array}$ & F crit \\
$\begin{array}{lllllll}\text { Between } \\
\text { Groups }\end{array}$ & 0.01668474 & 3 & 0.00556158 & 1.27 & 0.33 & 3.490 \\
\hline $\begin{array}{l}\text { Within } \\
\text { Groups }\end{array}$ & 0.05260161 & 12 & 0.00438347 & & \\
\hline Total & 0.06928635 & 15 & & & \\
\hline
\end{tabular}

\section{Discussion}

The results were statistically insignificant and failed to reject the null hypothesis about the relationship between materials and techniques. A marginal numerical advantage was observed for VPES over PVS. Siadat et al. $(12,13)$ observed a smaller discrepancy for VPES and suggested it as a material of choice for direct and indirect impression techniques Higher tensile strength and better flow properties of VPES can make it more advantageous and preferred to other impression materials. Baig et al. (11) determined that the accuracy of the VPES impression material was comparable with that of PE for multi-implant abutment level. Kurtulmus et al. (17) and Vojdani et al. (32) compared the VPS, VPES, and PE impression materials' accuracy in angulated implants, and found no significant differences among the compared impression materials. The accuracy was marginally higher for PVS, owing to elastic recovery. This study determined that VPES exhibited less distortion compared with PVS impression materials. The differences observed can be attributed to the higher number of implants considered in the present study, and the superiority can be related to the elastic properties of the considered materials.

Only a few studies evaluated situations with more than six implants and the impact of distortion for scenarios with many implants. This study determined the influence of eight implants, different impression materials, and techniques. The higher number of implants engages the elastic recovery properties of the materials owing to the increase in linear and rotational forces. Unlike earlier studies, the results of this study can be impacted by the higher number of implants and the properties of the used impression materials.

The majority of the existing studies used reference models made of acrylic or simulated materials $(11,28)$. These materials can affect the studies' outcomes, owing to their dimensional changes. This limitation was reduced in this study by using metallic reference models.

The present study found no statistically significant difference between the splinted and non-splinted impression techniques ( $f(1.27)=3.490, p=0.33$ ). This is consistent with the findings reported by the majority of existing studies. Al-Quran et al., Papaspyridakos et al., Naconecy et al., Ongul et al., Hariharan et al., and Kim et al. showed that the splinted technique is better than the non-splinted implant impression technique $(7,20,21,33-35)$. The variability in the observations reported in a few literature studies can be owing to different study designs, implant systems, different splinting materials, inaccurate repositioning of impression copings, different implant angulations, and expansion of stone materials.

In this study, a pattern resin was used as the splinting material. The splint was made prior to the impression making, to reduce polymerization shrinkage. The splint was sectioned and reconnected to the impression copings. The retentive design of the impression coping was an internal hexagonal connection that produced less vertical displacement. Machine intolerance was reduced by using novel analogues and impression copings. Significant evidence exists in literature suggesting that the PVS material is ideal for the direct impression technique, owing to its good rigidity and ability to prevent rotation of implant components. The VPES material is also an ideal impression material. It is hydrophilic and has properties comparable to those of the PVS material. The deviations found in the present study were within statistically acceptable limits, similar to the observations reported by Ebadian et al. (36). Extreme caution and standard recommendations were adhered to when making implant impressions using materials and techniques. The present study had some limitations. The present study used a stock impression tray. Additional studies using other techniques, different impression trays, and addressing a variety of realistic and clinically relevant scenarios are still required.

\section{Conclusion}

Irrespective of the technique and material, the linear and rotational distortion values were within the acceptable range. Therefore, it can be concluded that the casts fabricated from VPS or PVS impression materials provide similar dimensional accuracy regardless of the implant splinting method.

Türkçe Özet: Vinil polieter ve polivinil siloksan ölçü materyallerinin çoklu implantlar için direk implant ölçü tekniğinde boyutsal doğruluğu. Amaç: Bu çalışma, simule edilmiş dişsiz alt çenelere yerleştirilen birden fazla implant için kullanılan splintlenmiş (S) ve splintlenmemiş (NS) direk açık ölçü tekniğinde polieter (VPES) ve polivinil siloksan (PVS) ölçü materyallerinin boyutsal doğruluğunu karşılaştırmıştır. Gereç ve Yöntem: Klinik durumu simule etmek için paslanmaz çelikten implant analogları için sekiz in- 
ternal bağlantıya sahip paslanmaz çelik bir alt çene modeli üretilmiştir. Akrilik reçine ile splintlenmiş vey splintlenmemiş direk ölçüler VPES ve PVS materyalleri kullanılarak alınmıştır. Yetmiş-iki örnek kullanılan ölçü tekniği ve materyallerine göre dört gruba ayrılmıştır. Modellerin boyutsal doğruluğu üç farklı eksende bilgisayarlı koordinat ölçüm makinesi (CMM) kullanılarak ölçülmüş ve istatistiksel olarak karşılaştırılmıştır. Bulgular: VPES ve PVS ölçü maddelerinin distorsiyon değerleri arasında anlamlı bir farklılık bulunmamıştır. Benzer şekilde, splintlenmiş ve splintlenmemiş gruplarda da VPES ve PVS ölçü maddelerinin distorsiyon değerleri arasında anlamlı bir farklılık bulunmamıştır. Sonuç: VPES ve PVS ölçü maddelerinden elde edilen modeller implant splintlenme metodu gözetmeksizin benzer doğruluk göstermektedir. Anahtar Kelimeler: dental implantlar; direk ölçü; polieter, polivinil siloksan, boyutsal doğruluk

Ethics Committee Approval: The study was approved by the institutional review board (SRMDC/IRB/2015/MDS/NO:202).

Informed Consent: Not required.

Peer-review: Externally peer-reviewed.

Author contributions: RR and NGC participated in generating the data fort he study. RR, NGC and KVA participated in gathering the data fort he study. RR, NGC and BM participated in the analysis of the data. RR and NGC wrote the majority of the original draft of the paper. RR, NGC, KVA and BM participated in writing the paper. RR, NGC and KVA have had access to all of the raw data of the study. All authors have reviewed the pertinent raw data on which the results and conclusions of this study are based. All authors have approved the final version of this paper. All authors guarantee that all individuals who meet the Journal's authorship criteria are included as authors of this paper. All authors participated in designing the study.

Conflict of Interest: The authors had no conflict of interest to declare.

Financial Disclosure: The authors declared that they have received no financial support.

\section{References}

1. Buser D, Janner SF, Wittneben JG, Brägger U, Ramseier CA, Salvi GE. 10-year survival and success rates of 511 titanium implants with a sandblasted and acid-etched surface: a retrospective study in 303 partially edentulous patients. Clin Implant Dent Relat Res 2012;14:839-51. [CrossRef]

2. Ravald N, Dahlgren S, Teiwik A, Gröndahl K. Long-term evaluation of Astra Tech and Brånemark implants in patients treated with full-arch bridges. Results after 12-15 years. Clin Oral Implants Res 2013;24:1144-51. [CrossRef]

3. Arora A, Upadhyaya V, Parashar KR, Malik D. Evaluation of the effect of implant angulations and impression techniques on implant cast accuracy - An in vitro study. J Indian Prosthodont Soc 2019;19:149-58. [CrossRef]

4. Bhakta S, Vere J, Calder I, Patel R. Impressions in implant dentistry. Br Dent J 2011;211:361-7. [CrossRef]

5. Yokoyama S, Wakabayashi N, Shiota M, Ohyama T. Stress analysis in edentulous mandibular bone supporting implant-retained 1-piece or multiple superstructures. Int J Oral Maxillofac Implants 2005;20:578-83.

6. Balamurugan T, Manimaran P. Evaluation of accuracy of direct transfer snapon impression coping closed tray impression technique and direct transfer open tray impression technique: an in vitro study. J Indian Prosthodont Soc 2013;13:226-32. [CrossRef]

7. Al Quran FA, Rashdan BA, Zomar AA, Weiner S. Passive fit and accuracy of three dental implant impression techniques. Quintessence Int 2012;43:119-25.

8. Abduo J, Bennani V, Waddell N, Lyons K, Swain M. Assessing the fit of implant fixed prostheses: a critical review. Int J Oral Maxillofac Implants 2010;25:506-15.
9. Ender A, Mehl A. Accuracy of complete-arch dental impressions: a new method of measuring trueness and precision. J Prosthet Dent 2013;109:121-28. [CrossRef]

10. Al-Abdullah $\mathrm{K}$, Zandparsa $\mathrm{R}$, Finkelman $\mathrm{M}$, Hirayama $\mathrm{H}$. An in vitro comparison of the accuracy of implant impressions with coded healing abutments and different implant angulations. J Prosthet Dent 2013;110:90-100. [CrossRef]

11. Baig MR, Buzayan MM, Yunus N. Accuracy of a new elastomeric impression material for complete-arch dental implant impressions. J Investig Clin Dent 2018;9:e12320. [CrossRef]

12. Siadat $H$, Saeidi $Z$, Alikhasi $M$, Zeighami S. Comparative evaluation of the effect of impression materials and trays on the accuracy of angulated implants impressions. J Clin Exp Dent 2018;10:e1096-102. [CrossRef]

13. Saini HS, Jain S, Kumar S, Aggarwal R, Choudhary S, Reddy NK. Evaluating the Effect of Different Impression Techniques and Splinting Methods on the Dimensional Accuracy of Multiple Implant Impressions: An in vitro Study. J Contemp Dent Pract 2018;19:1005-12. [CrossRef]

14. Conrad HJ, Pesun IJ, DeLong R, Hodges JS. Accuracy of two impression techniques with angulated implants. J Prosthet Dent 2007;97:349-56. [CrossRef]

15. Baig MR. Accuracy of impressions of multiple implants in the edentulous arch: a systematic review. Int J Oral Maxillofac Implants 2014;29:869-80. [CrossRef]

16. Izadi A, Heidari B, Roshanaei G, Allahbakhshi H, Fotovat F. Comparative Study of Dimensional Accuracy in Three Dental Implant Impression Techniques: Open Tray, Closed Tray with Impression Coping, and Snap Cap. J Contemp Dent Pract 2018;19:974-81. [CrossRef]

17. Kurtulmus-Yilmaz S, Ozan O, Ozcelik TB, Yagiz A. Digital evaluation of the accuracy of impression techniques and materials in angulated implants. J Dent 2014;42:1551-59. [CrossRef]

18. Herbst D, Nel JC, Driessen CH, Becker PJ. Evaluation of impression accuracy for osseointegrated implant supported superstructures. J Prosthet Dent 2000;83:555-61. [CrossRef]

19. Assuncao WG, Filho HG, Zaniquelli O. Evaluation of transfer impressions for osseointegrated implants at various angulations. Implant Dent 2004;13:358-66. [CrossRef]

20. Papaspyridakos P, Benic GI, Hogsett VL, White GS, Lal K, Gallucci GO. Accuracy of implant casts generated with splinted and nonsplinted impression techniques for edentulous patients: An optical scanning study. Clin Oral Implants Res 2012;23:676-81. [CrossRef]

21. Naconecy MM, Teixeira ER, Shinkai RS, Frasca LC, Cervieri A. Evaluation of the accuracy of 3 transfer techniques for implantsupported prostheses with multiple abutments. Int J Oral Maxillofac Implants 2004;19:192-98.

22. Kim S, Nicholls JI, Han CH, Lee KW. Displacement of implant components from impressions to definitive casts. Int J Oral Maxillofac Implants 2006;21:747-55.

23. Pera F, Pesce $P$, Bevilacqua M, Setti P, Menini M. Analysis of different impression techniques and materials on multiple implants through 3-dimensional laser scanner. Implant Dent 2016;25:232-37. [CrossRef]

24. Nakhaei M, Madani AS, Moraditalab A, Haghi HR. Threedimensional accuracy of different impression techniques for dental implants. Dent Res J (Isfahan) 2015;12:431-37. [CrossRef]

25. Walker MP, Alderman N, Petrie CS, Melander J, McGuire J. Correlation of impression removal force with elastomeric impression material rigidity and hardness. J Prosthodont 2013;22:362-66. [CrossRef]

26. de Avila ED, Barros LA, Del'Acqua MA, Castanharo SM, Mollo Fde A Jr. Comparison of the accuracy for three dental impression techniques and index: an in vitro study. J Prosthodont Res 2013;57:268-74. [CrossRef]

27. Alexander Hazboun GB, Masri R, Romberg E, Kempler J, Driscoll CF. Effect of implant angulation and impression technique 
on impressions of Nobel Active implants. J Prosthet Dent 2015;113:425-31. [CrossRef]

28. Selvaraj S, Dorairaj J, Mohan J, Simon P. Comparison of implant cast accuracy of multiple implant impression technique with different splinting materials: An in vitro study. J Indian Prosthodont Soc 2016;16:167-75. [CrossRef]

29. Haghi HR, Shiehzadeh M, Nakhaei M, Ahrary F, Sabzevari S. Effect of technique and impression material on the vertical misfit of a screw-retained, three-unit implant bridge: An in vitro study. J Indian Prosthodont Soc 2017;17:41-7. [CrossRef]

30. Joseph TM, Ravichandran R, Lylajam S, Viswabharan P, Janardhanan K, Rajeev S. Evaluation of positional accuracy in multiple implants using four different splinting materials: An in vitro study. J Indian Prosthodont Soc 2018;18:239-47. [CrossRef]

31. Tabesh M, Alikhasi M, Siadat H. A Comparison of implant impression precision: Different materials and techniques. J Clin Exp Dent 2018;10:e151-7.
32. Vojdani M, Torabi K, Ansarifard E. Accuracy of different impression materials in parallel and nonparallel implants. Dent Res J (Isfahan) 2015;12:315-22. [CrossRef]

33. Ongül D, Gökçen-Röhlig B, Şermet B, Keskin H. A comparative analysis of the accuracy of different direct impression techniques for multiple implants. Aust Dent J 2012;57:184-9. [CrossRef]

34. Hariharan R, Shankar C, Rajan M, Baig MR, Azhagarasan NS. Evaluation of accuracy of multiple dental implant impressions using various splinting materials. Int J Oral Maxillofac Implants 2010;25:38-44.

35. Kim JH, Kim KR, Kim S. Critical appraisal of implant impression accuracies: A systematic review. J Prosthet Dent 2015;114:18592. [CrossRef]

36. Ebadian B, Rismanchian M, Dastgheib B, Bajoghli F. Effect of different impression materials and techniques on the dimensional accuracy of implant definitive casts. Dent Res J (Isfahan) 2015;12:136-43. 